\title{
Role of the "Green" Philosophy and Bionics on the Development of Eco- Design Clothing
}

\author{
${ }^{1}$ Klara H. Karamova, ${ }^{2}$ Aleksandr A. Mukhametshin, ${ }^{3}$ Madina M.Makhmutova, ${ }^{4}$ Salavat F. Usmanov \\ ${ }^{1-3}$ Kazan Federal University, Kazan, Russia \\ ${ }^{4}$ Kyrgyz-Russian Slavic University, Bishkek, Kyrgyzstan \\ Email: klara_karamova_kazan@mail.ru
}

Received: 23 ${ }^{\text {rd }}$ July 2019, Accepted: $10^{\text {th }}$ August 2019, Published: $31^{\text {st }}$ August 2019

\begin{abstract}
The article is devoted to the fundamental role and evolution of costume in human ethnography, its material and spiritual culture, public relations and family life, the disclosure of its nature-like characteristics and the impact on the development of modern trends in the world of the clothing industry.

Folk costume as one of the most essential types of decorative and applied art is of the greatest interest and fully embodies the diverse connections of a person with the outside world. Its design is one of the most dynamic types of the whole variety, all changes in the life of society are reflected in it through the use of current signs and symbols.

The authors carried out the systematic work on the study of "Green" philosophy, the principle of respectful management of the environment. Careful attitude to nature and the search for means of preserving the environment through eco-design clothing, unique ways to improve the eco-system and acute pollution control due to the use of natural and eco-materials in fabrics and clothing are taken into consideration.

The laws of shaping in the design of the national costume in the context of "Green" philosophy and bionics together with the historical method allow to consider the evolution of the formation and accumulation of knowledge about bionic principles and formulate its fundamental importance for the development of artistic culture.
\end{abstract}

\section{Keywords}

“Green” Philosophy, Bionics, Folk Costume, Fashion, Environmental Friendliness, Nature Conformability.

\section{Introduction}

Nowadays processes of integration, mechanization and standardization are not only characteristics that help huge corporations to achieve quick results, but also major factors leading to sad consequences which manifested themselves not only in the formation of modern clothing, but also in other areas, for example, in standard buildings.

We must admit that a great amount of objects that have already lost their individuality together with low-quality artificial materials that appeared recently cause no positive emotions and aesthetic pleasure, but have a serious negative impact on human perception.

Many environmental issues excite the minds of mankind and today have acquired the character of an international catastrophe. The problem of how to get rid of the harmful effects on a person of this phenomenon, or the search for the possibility of its leveling, has become a painful one. The promotion of ecology conservation ideas, both culturally and scientifically, will be fruitful. Among such powerful art forms as television and cinema, there is fashion design. Fashion should be in tune with the environment and concern for nature.

\section{Methods}

Clothing design was one of the first to quickly respond to the need for deliberate attention to the environmental problem, since it has not only an aesthetic, but also a direct physiological effect on a person.

The search for new materials, new technologies for dyeing fabrics using natural ingredients, the use of recycled materials in compliance with the standards, the restoration of folk crafts play an important role in creating clothes. This led to the growth from theory that does not enjoy public acceptance into practice that is sustainable in all directions, called "eco-design", which is sometimes called: "green design" or "green philosophy", "bionic design", which can work dialectically in the aggregate. These are synonyms revealing the jump from one quality to another. In the environmental direction, working in accordance with the principle of preserving health, it is necessary to avoid the use of harmful contents in the composition of tissues that may have an adverse effect on health, and natural tissues - a significant improvement in the hygienic features of products (the ability to absorb dust, liquid, vapors, air, water, heat), in maintaining and restoring the balance between the artificial and the natural environment, seeking means for harmony in relation of indicators of physical and chemical reactions of the existence of these media [Abdullin I. Sh The effect of plasma flow on the microstructure and properties of textile materials for designed clothing models [1].

"Green" philosophy, the principle of respectful environmental management, is relevant, therefore for modern citizens of the country a careful attitude to the gifts of Mother Nature should become a way of life with careful attitude to nature and the search for means of preserving the environment, through eco-design clothing. Today, new ways to improve the eco-system and pollution control using natural and eco-friendly materials in fabrics and clothing are being created. 
The theme of nature is the subject of study for a number of modern scientific research, and for the designer it serves as an inexhaustible creative source. Costume design is one of the most mobile types of design, all changes in society are reflected in it through the costume language: the use of relevant signs and symbols allows you to speak the modern language of fashion.

We set the following tasks: to consider the patterns of formation in the design of the national costume in the context of "green"philosophy or bionics; to study the historical method, which allows to consider the evolution of the formation and accumulation of knowledge about bionic principles and to formulate its fundamental importance for the development of artistic culture.

Ethnologists trace various driving forces for transforming the human culture in the course of analyzing its historical development, including the influence of environmental causes, ethnic impact, etc.

At the beginning of the 21 st century, awareness and rethinking of the role of man in the world took place, and on the new wave of "green" philosophy, the main principle was a harmonious relationship with nature. Humanity exists because of it, and owes much to it. Any change to our planet has an impact and can be detrimental to both physical, emotional and psychological health of people themselves.

Many young modern designers and sometimes already recognized ones as they say "do not bother." They look through magazines, go to fashion shows, watch fashion by fashion channel and take ideas from other designers for their future creations. Certainly, not in pure form by copying, but by slightly changing the color, fabric, design of the product. Thus, they make an attempt to create a completely new product of creativity. This is a well-known and common method of work. The most promising would be the creation of new materials with new operational properties that have the ability to acquire desired properties, as well as the development of harmless and waste-free production technologies in order to obtain environmentally friendly products.

\section{Results and Discussion}

A look at human activity as a kind of continuation of natural organization can be found in the statements of Democritus, who initiated the theory of art, technology, craft, etc. - this is an "imitation" of nature. Theories of imitation were followed by Plato and Aristotle, considering imitation as the defining sign of art. I.M. Sechenov [2]. Modern bionics is the most favorite source of inspiration for fashion designers and designers. If you study the flora and fauna, you can discover a lot of interesting and useful things. Not only a lot of technology built in the likeness of plants, animals and insects, but also dresses, copying butterflies and flowers. Mimesis (desire to give way) became an objective prerequisite for the emergence of the bionic principle in clothing design.

Diverse connections of a person with the world around him are reflected in the aesthetics of the ornament, connected with the philosophy of the people, with their attitude to life, with its concepts and world perception. The nature around us is an excellent object for artistic styling. A striking example is the development of the "animal style" in the art of the ancient peoples of Asia and Europe. "Islimi" (a garland of flowers) - a bright element of the decor of the Middle Eastern region, the almond shape of "bo-house" - reminds a floral motif, "flower" is one of the main elements of a floral ornament. Anthropomorphic, or humanoid ornament consists of female or male figures.

Folk costume, as a whole, personifies the various connections of a person with the world, unlike other types of decorative and applied art, is associated with a whole complex of objects that form their ensemble through the composition, color and ornament, rhythmic system of construction, volume-plastic forms, implemented in a cut. Any national dress contains not only its own flavor, but is also filled with the age-old wisdom and life itself.

Folk costume is inherent in semiotic, i.e. sign character, it concerns traditional clothes of any ethnos. In a mediated form, it always expresses certain ethnic traditions, since it is through clothing that the individuality of a particular user is manifested. One of the most important properties of artistic folk thinking is metamorphic, i.e. a combination of natural cultural phenomena according to a generalizing feature or property.

From the point of view of aesthetics, the abundance of details, iconic systems, the richest women's suit, in which there is a conditional division into "tiers"can be of great value. Researcher B. A. Rybakov presents a costume as a model of the Universe, where symbols of ornamental patterns correspond to different tiers. So, for example, at the very top, the ornaments reflect the symbols of the sky, on the upper edge of the clothes are birds, rain; on the lower tier - vegetation, seeds and symbols of the earth [3].

The traditional national costume of the Turkic peoples could not be invented overnight, but was the result of a long evolutionary process.

If you make a digression into history, then in antiquity, there was a great influence on the analysis of the process of human visual perception of objects of nature in the absence of an artificial environment, which resulted in an exceptionally bionic characteristic of the form and content of the costume. The symbiosis of nature and technology of clothing is manifested most clearly. Understanding of the internal logic of formation at that time was unconscious, elemental, intuitive.

How did it all start? [4] Some researchers claim that the clothes appeared so that the person would not be cold. Then it had to be fixed to hold on the body of a person. Further, as civilization developed, changes in style and design of clothes took place. Clothing appeared in the early stages of human development. The man made his clothes from branches, grass, leaves, straw. The main material for primitive clothing everywhere was animal skin. People learned how to create tissue from plant fibers. All clothes - both male and female - looked like a dress or a raincoat. It differed only in length. 
The specific needs of people in the tissues and other materials for the manufacture of clothing evolved over time and under the influence of many factors - natural, climatic, historical, ethnic, socio-economic.

The costume is from its inception to its most recent forms, a social sign distinguishing one class of society from another, from one nation to another, one profession from another, one individuality from another, etc.

Folk costume (clothing and jewelry) is a complex structure, including numerous types of upper and lower clothing, hats, shoes, jewelry. The formation of the traditional costume of the peoples in the world is associated with the use of products of a whole complex of various types of folk decorative and applied arts that form its ensemble. [5,6]

\section{Findings}

The essence of environmental design is that, taking an example from nature, to simplify, improve a person's life, taking into account his needs, taste preferences, aesthetics requirements, as well as in accordance with the concept of comfort, convenience and price, focuses on the following indicators:

1. The ecological approach to design, the development of a more efficient chain of processes for designing, manufacturing, and consuming resources and their further utilization. Items made from natural material can last longer if they are recycled.

2. The use of environmental dyes. Consideration is taken of a large number of aspects: the protection of the environment by the manufacturer and the observance of the rights of workers involved in this production. Rejection of the use of synthetic materials and artificial dyes in favor of recycled materials. It is important to emphasize attention to the safety of the product that has no harmful effects on health, the production of nanotubes that are safe for the environment.

3. The use of materials of animal origin - fur, horsehair, all varieties of leather, whalebone, etc., as well as for the production of fabrics of fast-growing bamboo, nettle, algae, eucalyptus, hemp, which are rapidly recoverable resources. [7]

Recently, a great variety of styles have become popular, using natural eco-friendly fabrics, materials for accessories (feathers, wood, jewelery made of stones, leather, wool yarn, shells, etc.): eco, ethno, western, casual, gypsy style, hippie, grunge, punk, folk, and the list goes on ... Boho has something in common with Western, Indian and cowboy styles. Often, the boho style is perceived close to the rural style, "country-eco", clothes made of cotton, flax, painted in natural colors, with white, gray, beige and brown shades. Characteristic elements are the following: jagged edges, ruffles, lace trim. In this style, cowboy boots and moccasins made of leather and suede can be used in combination with skirts, dresses, jeans, trousers and shorts; cowboy hats and hats in Mexican style with curved and lowered fields, as well as straw; feathers in headdresses are popular; shawls and scarves are worn in gypsy-pirate style, snoody, voluminous scarves, with tassels; fringe in bags, vests, ponchos, pendants and earrings, hair ornaments, that is, absolutely all elements of western style. It pushed and inspired designers to create products with feathers that resemble analogs of Indian jewelry. The decorations of the Indian peoples of North America and the southwestern North American tribes (therefore these styles are called "Southwestern") are massive, made of silver and stones, of bone beads, shells, etc .; bolo ties; cowboy belts, including with buckles Indian masters, in the subject of Wild West. The prints include images of Indians and Native American paraphernalia - wigwams, bison, eagles and wolves, feathers, bull skulls. Actual lace and macrame white, beige. Shoes: cowboy and indian boots, boots and ankle boots, platform sandals, gladiator sandals, beaded shoes and etc.

Popular fur clothing and shoes, blouses with wide sleeves with elastic or cuffs, loose sweaters, tank tops, long cardigan coats, skirts with lace and frills, with bright floral prints. In general, the finish is varied - ruffles, tassels, fringe, embroidery, beads in combination with a haircut, mostly loose hair, stabbed in a bun or loosely assembled in tails, woven into a braid. Also boho style combines bright details of national costumes of many nationalities.

The commitment to the environment, naturalness and uniqueness have made eco-design, eco-fashion megapopular areas in many countries where there are enough resources and raw materials for it. A boom swept the world, ecofriendly products attract the attention of consumers who care about their health and are not involved in environmental pollution, they make the choice that, long before the factories, was made by nature itself. Communication with nature is fashionable, to be "eco-friendly", ethical in relation to nature - has long been considered of good taste, everything recognizes the laws of harmony. Naturalness becomes even something elite, while not necessarily, an object made of valuable wood or alloy, and if the material is accepted as rare, disappearing in nature, it is unethical, and therefore not environmentally friendly. [8,9]

The theme of nature is the subject of study for a number of modern scientific research, and for the designer it serves as an inexhaustible creative source. Costume design is one of the most

mobile types of design, all changes in the life of society are reflected in it through the costume language: the use of current signs and symbols allows you to speak the modern language of fashion.

\section{Conclusion}

Eco-design clothing is not just fashion. There are a number of problems that are solvable only with the effective promotion of the idea of sustainable development and the introduction of an appropriate system of training in educational institutions to foster an ecological and healthy lifestyle. Modern production should minimize the harm caused to the environment, making a choice in favor of creating beautiful, practical and convenient things made from local materials according to long-established technologies. [10] 
Clothing is an important part of the culture of the people, along with its traditions, customs, music and national cuisine. Reunion with nature is the most important thing for eco-style, for bionics, for a comfortable existence of a modern person who lives in a world of high speeds in the era of nanotechnology dawn, therefore he turns again and again to nature asking for advice. Engineers are searching for technical solutions, studying the structure and functions of living organisms, the designers from time to time "consult" with wildlife, the ingenuity of which knows no boundaries, and it forces the Man to learn from their ancestors, observing nature and introducing them into their safe living space.

Bionic structures shaping the costume make it possible to endlessly balance between artificial and natural form, they define new conditions for the industrial production of garments. Clothing is an essential part of the culture of humans along with its traditions, customs, music, etc.

As a result of copying the structures of nature, systems can be created, firstly, performing specified functions, secondly, performing these functions with the highest possible perfection, and thirdly, being organically coherent spatial systems. Consequently, this approach involves the identification of the laws of the formation and functioning of the systems of nature, the specifics of the structural-functional relations and the subsequent use of these laws in the design of a suit.

\section{Acknowledgements}

The work is performed according to the Russian Government Program of Competitive Growth of Kazan Federal University.

\section{References}

[1] I.Sh. Abdullin "The effect of plasma flow on the microstructure and properties of textile materials for designed clothing models”, Bulletin Kazan. tehnol. un., № 6, pp. 59-64, 2010.

[2] I.M. Sechenov "Psychological studies", SPb.: Type. F. Sushchensky, 225 p., 1973.

[3] B.A. Rybakov "Paganism of ancient Russia", M.: Science, 789 p., 1987.

[4] B.A. Rybakov "World of history. The Beginning Centuries of Russian History", M .: Young Guard Series: Eureka, 1987.

[5] M.N. Mertsalova "The Poetry of the Folk Costume", Moscow, 244 p., 1988.

[6] Klara K. Karamova, Irina M. Mayorova, Gulnaz H. Myhtarova, Rezeda.A Fahrutdinova, Adnan M. Hakki DEVELOPMENT OF CREATIVE ACTIVITY OF STUDENTS-DESIGNERS METHOD OF METAPHORICAL ASSOCIATIVE CARDS (MAC)» «Amazonia oShttp://www.udla.edu.co/revistas/index.php/amazoniainvestiga/article/view/947 c. 279-286

[7] Galeeva Zukhra N., Yao Michail K., Emanova Juliana G., "Development of sustainable design: directions and problems", Amazonia Investiga, vol.7, Is.15, pp.196-201, 2018.

[8] Fakhrutdinova, A.V., Kadyjrova, L.H., Musina, K.I. Artistic and aesthetic education of students by the means of the national arts and crafts: the Tatarstan republic experience. Abstracts \& Proceedings of SOCIOINT 2017- 4th International Conference on Education, Social Sciences and Humanities. 10-12 July 2017, Dubai, UAE.- P.752-757.

[9] Gulnaz R. Akhmetshina, Michail K. Yao, Rasyh F. Salakhov, Kseniya G.Pozdnyakova. Typology and Stylistics of the Russian Empire Estates// Revista Publicando.- 2017. -4 No 12. (1). -709-717.- ISSN 1390-9304

[10] Gaptraupova, Zukhra N.; Emanova, Juliana G.; Salakhova, Rada I. About Socialization of Restored Mansions in Russia// REVISTA PUBLICANDO.- 2017.- Vol. 4(13).- P. 607 - 615. 